\title{
URBAN AND SUBURBAN FOOD PRODUCTION
}

\section{By Charles Lathrop Pack,}

President, National Emergency Food Garden Commission.

My friends, I rejoice with you as a fellow-citizen in all the town and city people of our country are doing for food production and food conservation. I have recently seen many community canneries so ably conducted throughout the country as to set a splendid example of productive thrift.

We are glad that the housewife is doing her part in this nationwide, food-producing and food-conserving movement. The work of gardening, of canning and of drying vegetables and fruits is abroad in the whole land from Maine to California, and from the Lakes to the Gulf, and has justified all the expectations of success. Let us consider for a moment what this means. It means that one million, one hundred and fifty thousand acres of city and town land are under cultivation this year-the largest part heretofore non-producing. Urban and suburban America today is a vast garden as the result of the impulse given to the nation by the National Emergency Food Garden Commission. This area of fruitfulness embraces back yards, vacant lots and hitherto untilled tracts of land in and around nearly every city, town and village in the country. Our country-wide survey locates nearly three million food gardens, but this is not the best of the story.

It is conservative to state that by the planting of gardens where none grew before the nation's food supply has been increased to the extent of more than $\$ 350,000,000$. The canning and drying movement has brought back to thousands of American households an art almost forgotten since our grandmothers' days. This particularly applies to the drying of vegetables and fruits which this year, in addition to canning, is being done by good housewives far beyond any anticipation.

There is much evidence that our food gardens are helping our people to feed themselves more reasonably. The Editor of the North American Review says in the September number:

Last spring, at garden-planting time we urged the increase of production, partly through intensified culture, to increase the yield per acre, and partly through the increase of acreage by the cultivation of neglected fields and even small plots in 
suburban and urban areas. How well this policy was executed is seen in the Report of the National Emergency Food Garden Commission, that the gardens of the country were this year more than trebled in area. Beyond question, this achievement has much to do with the fact that the increase in price of garden products in the year wias only twenty-two per cent, or less than one-fifth the increase in the price of breadstuffs.

The results will mean much for food this winter f.o.b. the pantry shelves of the homes of America and help us, by feeding ourselves, to feed our boys of the army and navy and our allies. Do we all realize that we already have a million men under arms in our army and navy and that there will be at least two million of them by spring? They must all be fed and the soldiers and people of France and England must be fed and to a large extent fed by us and we are going to do it. In the canning and drying of vegetables and fruits our women are contributing their share.

The glass jar manufacturers of this country have delivered to September 1 about one hundred and nineteen million quart glass jars. A survey of the household supply of jars used for canning and preserving in some twenty typical towns throughout the country shows that the housewives of America this year will use but one new jar to over three and one-quarter old glass jars on hand, and all of them, old and new, have been filled or will be filled. Thus you see that speaking in conservative terms the home women of our country will conserve more than four hundred and sixty million quart glass jars of vegetables and fruits-certainly three times what has been accomplished before. I think this is inspiring. The drying and dehydrating has also added very largely to the food supply by preserving vegetables and fruits and in this way providing the fruitfulness of summer for the needs of the winter.

The commission is of course gratified at the success of its work in behalf of food thrift. Great credit is due the press of the country for its splendid and liberal coöperation. The popular interest that has been aroused in gardening, canning and drying is significant of the American determination to neglect no opportunity to strengthen the nation's war-time position.

Much has been learned this year by town and city people about the cultivation and value of the soil and the conservation of its products, so that we may look with faith and courage to still greater esults for the next season, when the noed will be even more urgent. 
I think this is a hopeful picture, and in coming here today to meet you all, I come simply as another worker with the simple proposal that urban and suburban dwellers continue their good work in joining with us, that we may jointly and with the best intelligence that we can mutually bring to bear, all of us, contribute our part in fighting with food. We are going to do our duty in this hour of trial. The fact is that this war is as much our war as it is the war of Europe, and unless we can keep the women and children of our allies fed, the western line of defense may be thrown back toward the Atlantic seaboard, and it is well within possibilities in that case we would see the enemy's army even in Pennsylvania and at Philadelphia.

I want to praise the good women of this country because it is the women who really understand what the war means. It is my experience that the patriotic women of America have been practicing thrift and that they know full well how to practice economy without parsimony, but this year in addition they have added to their duties the patriotic work of food production and food conservation. A thrifty woman is a blessing to mankind, and the women know very much more about real thrift than the men. Many men are extravagant in matters of this kind and if they become thrifty, as they think, they in reality become stingy. Stinginess is not thrift. So, I say, all honor to the women of America who are doing their part.

We are going to win this war and we are going to win it by fighting with food. You cannot starve Germany; Ambassador Gerard has told us so, and from the available evidence I believe he is right, but we will starve our allies if we are so shortsighted and small and mean and unpatriotic as not to deserve the name of Americans. This must not be! It will not be!

We face a race of people under a government intent upon the mastery of the world. The war seems far away to most of us, but we are in reality fighting for our national existence and our fate as a free people. We will realize this more when the great stream of wounded and maimed of our soldier boys are sent back to us from France. But, as I say, we are going to win this war. Our soldiers are going to do their part. We are sending our friends and our sons to the front and we who are at home not fit to carry arms, men and women, can carry on the good fight and do our part quite as well as the man with the gun. Thrift will do her part in securing success 
but without thrift we will fail. I am sure you are doing your part and I feel sure of victory - a victory of arms and a victory of thriftand when that victory comes there may be erected a simple monument commemorating this greatest event in modern history, and I hope there will be inscribed on it these words: For Democracy and Civilization-A War Won by Free Men and Free Women for Humanity.

\title{
THE POIN'T OF ORIGIN PLAN FOR MARKETING
}

\author{
By A. B. Ross, \\ Executive Secretary, Department of Food Supply, Committee of Public Safety \\ of Pennsylvania.
}

The object of this plan is the feeding of each community, as far as possible, with food from within its own natural trading area, and the laying by of dried, canned and stored reserves of food from local sources; the keeping of community money within the community area, and using it for community development; the making of each community a self-contained, self-sustaining, compact trading unit; the development of the smaller community centers into exporters of food to the larger cities, reversing the present system whereby natural food-producing areas are importing food.

The plan is not arbitrary; it has been built up in ten years of patient study, labor and experimental marketing carried on jointly by farmers and myself. It is readily within the comprehension of the farmer, and, in its present form, has met with the instant, unqualified and enthusiastic endorsement of the great mass of farmers to whom it has been submitted, and who joined the ranks of nonproducers of city food because they could not make production profitable. It requires no new business machinery.

It incorporates three fundamentals of economic distribution:

a. Reduces transportation to a minimum.

b. Organizes and standardizes food instead of seeking to organize and standardize farmers.

c. Places responsibility exactly where it belongs.

The Transportation Situation. Altoona, Pa., furnishes a typical illustration of the system of food supply ruling interior cities and 